4 Blackman JA, Selzer SL, Patil S, Van Dyke DC. Autistic disorder associated with an isodicentric Y chromosome. Dev Med Child Neurol 1991;33:162-6.

5 Lin CC, Meyne J, Ramakrishnan S, et al. Determining the origins and the structural aberrations of small marker chromosomes in two cases of $45, \mathrm{X} / 46, \mathrm{X}+$ mar by use of chromosome-specific DNA probes. $\mathrm{Am} \mathcal{F} \mathrm{Med}$ Genet 1990;37:71-8.

6 Bernstein R, Steinhaus KA, Cain MJ. Prenatal application of fluorescent in situ hybridization (FISH) for identification of a mosaic Y-chromosome marker, idic (Yp). Prenat Diagn 1992; 12:706-16.

7 Page DC. Hypothesis. An Y chromosomal gene causes gonadoblastoma in dysgenetic gonads. Causes gonadoblastoma in dysge

8 Fernández JL, Pereira S, Campos A, Goyanes V. Pseudoisodicentric nature of a normal length non-fluorescent Y chromosome. Ann Genet (Paris) 1994;37:215-7.

9 Haaf T, Warburton PE, Willard HF. Integration of human $\alpha$-satellite DNA into simian chromosomes: centromere protein binding and disruption of normal chromosome segregation. Cell 1992;70:681-96.

10 Vogt P. Code domains in tandem repetitive DNA sequence structures. Chromosoma 1992;101: 585-9.

11 Peretti D, Maraschio P, Lambiase S, et al. Indirect immunofluorescence of inactive centromeres as indicator of centromeric function. Hum Genet 1986;73:12-6.

12 Haaf $T$, Schmid $M$. Y isochromosome associated with a mosaic karyotype and inactivation of the centromere. Hum Genet 1990; 85:486-90.

13 Maraschio P, Zuffardi O, Caiulo A, et al. Deletion of specific sequences or modification of centromeric chromatin are responsible for $\mathrm{Y}$ chromosome centromere inactivation. Hum Genet 1990;85:491-4.

14 Tyler-Smith C, Willard HF. Mammalian chromosome structure. Curr Opin Genet Dev 1993; 3:390-7.

\section{Familial predisposition to both male and female germ cell tumours?}

A minority of testicular teratomas are recognised to be familial. ${ }^{1}$ Some occur as part of the spectrum of cancers in the Li-Fraumen syndrome; however, the genetic basis of the majority of familial cases is unknown. This has prompted the formation of a Linkage Consortium to identify genes causing testicular teratomas. As one of the participating centres we have been ascertaining familia cases from a registry of testicular teratoma patients at the Royal Marsden Hospitals Among these cases we have identified three families which suggest that a common genetic basis exists between some male and female germ cell tumours.

The first family was identified through an index case who presented with a seminoma at the age of 51, his brother had had a testicular teratoma at the age of 28 , and their cousin an endodermal sinus tumour of the ovary diagnosed at 32 years. In the second family the index case presented with an undifferentiated malignant teratoma at 28 years of age and his sister was diagnosed with bilateral mature teratomatous cysts at the age of 39. In the third family the index case presented with a retroperitoneal teratoma at 26 years and his sister was diagnosed with an ovarian dysgerminoma at 45 years. None of these families had any features indicative of the Li-Fraumeni syndrome or any other cancer family syndrome, suggesting the identification of a previously unrecognised association. This is supported by two reports of single families with ovarian and testicular germ cell tumours ${ }^{23}$ and a family with multiple cases of dysgerminoma. ${ }^{4}$ The three families we report were identified from a database of 2000 teratoma patients, suggesting that in $0.2 \%$ of pedigrees a female member will develop a germ cell tumour This may be an underestimate since pedigree information on all 2000 index cases has not been verified and many mature teratomatous cysts are asymptomatic and go undiagnosed.

Whether an association between male and female germ cell tumours is the result of the inheritance of a single gene with effects on both ovary and testis or a consequence of the action of modifying genes will only be established when the gene or genes causing testicular teratomas are identified.

This work is supported by the Cancer Research Campaign and the Bob Champion Cancer trust. $\mathrm{RAH}$ is supported by a CRC clinical research fellowship.

R A HUDDART C THOMPSON R HOULSTON Institute of Cancer Research, 15 Cotswolds Road, Belmont, Surrey SM2 5NG, UK

R A HUDDART E J NICHOLLS A HORWICH

The Royal Marsden Hospital, Downs Road, SM2 SPT, UK

1 Forman D, Oliver RTD, Brett AR, et al. Familia testicular cancer: a report of the UK family register, estimation of risk and an HLA class sib pair analysis. $B r f$ Cancer 1992;65:255-62. 2 Trentini GP, Palmieri B. An unusual case of gonadic germinal tumour in a brother and sister. Cancer 1974;33:250-5.

3 Yule SM, Dawes PJDK, Malcolm AJ, Pearson ADJ. Occurrence of seminoma and dysgerminoma in father and daughter. Paediat Haematol Oncol 1994;11:211-13.

4 Jackson SM. Ovarian dysgerminoma in three generations. F Med Genet 1967;4:112-13.

\section{BOOK REVIEWS}

If you wish to order or require further information regarding the titles reviewed here, please write to or telephone the BMJ Bookshop, PO Box 295, London WC1H 9JR. Tel 0171383 6244. Fax 0171383 6662. Books are supplied post free in the UK and for BFPO addresses. Overseas customers should add $15 \%$ for postage and packing. Payment can be made by cheque in sterling drawn on a UK bank or by credit card (Mastercard, Visa, or American Express) stating card number, expiry date, and full name. (The price and availability are occasionally subject to revision by the Publishers.)

DNA Cloning 2: A Practical Approach. Expression Systems. Editors D M Glover, B D Hames. (Pp 255; £25.00.) Oxford: IRI Press. 1995. ISBN 0-19-963478-5.

The many advances and widespread use of prokaryotic and eukaryotic protein expression systems is reflected in the increase in the size of this text, from four chapters in the first edition 10 years ago, to a complete volume in 1995 with an additional volume dedicated to mammalian systems. This volume provides a clearly written text covering the major aspects of protein expression, from the isolation of a cDNA through to the purification of the expressed protein product and the generation of antibodies to that product. Systems covered include fusion and non-fusion protein expression in $E$ coli, protein production, two hybrid interaction screening in yeast, and baculovirus expression of protein in yeast and insect cells. The generation of polyclonal and monoclonal antibodies to expressed proteins is also covered in some detail. The text provides sufficient introduction and background for a complete understanding of the methodology under discussion, with detailed protocols presented in clearly marked boxes within the text, often containing handy notes and tips from the authors' own laboratories. This volume would be entirely sufficient for someone outside the field to isolate a cDNA to a protein of interest, clone into an appropriate expression vector, achieve soluble protein expression, and raise antibodies as well as investigate possible other protein-protein interactions. It is more than a list of protocols, it provides a concise account of the "whys and wherefores" of the methods being used. As the individual chapters "stand alone", there is some duplication where the reader is given methods for SDS-PAGE or western blotting in more than one chapter, but this is a minor irritation. The only aspect of protein expression that is not covered, neither in this volume nor apparently in volume 4 , is the production of protein in rabbit reticulocyte lysates, a rapid method for the generation of small quantities of correctly folded protein (often labelled) for the determination of protein-protein interactions or other functional assay. It is inevitable, however, as the editors hope, that this book will become "messy and dog-eared" from constant use in the laboratory, both as a source of reference and as a practical guide.

STEVE WINDER

Developmental Mechanisms of Heart Disease. Editors E B Clark, R R Markwald, A Takao. (Pp 679; \$159.00.) New York: Futura Publishing Company Inc. 1995.

The 4th International Symposium on Etiology and Morphogenesis of Congenital Heart Disease was held in Tokyo in November 1993. The editors' stated aim in this volume is to allow the participants of the symposium to share their knowledge with a broader audience of scientists and clinicians. The book includes the symposium papers as well as commissioned overview chapters and has been divided into six main sections and 72 papers or overview chapters.

The first section introduces molecular biology and the molecular analysis of cardiac developmental phenotypes including gene expression during embryonic development. The second section extends the application of molecular biology to medical genetics especially the cardiomyopathies. The third and largest section overall is divided into four overviews and 26 papers related to wider ranging aspects of cardiogenesis including regulation of chick and rat heart development as well as teratogenic cardiac abnormality. Aspects of the functional development of the heart are contained in the final section.

The penultimate section entitled "Human and Animal Models of Cardiac Defects" is of particular interest to clinicians covering conotruncal abnormalities and lateralisation defects as well as an interesting review of 